\title{
The feather mites of nightjars (Aves: Caprimulgidae), with descriptions of two new species from Brazil (Acari: Xolalgidae, Gabuciniidae)
}

\author{
Fabio Akashi Hernandes
}

Departamento de Zoologia, Universidade Estadual Paulista, Rio Claro, São Paulo, Brazil

\begin{abstract}
Two new species of feather mites are described from nightjars (Caprimulgiformes: Caprimulgidae) of Brazil: Hartingiella neotropica sp. n. (Xolalgidae) described from Hydropsalis parvula (Gould) and Paragabucinia brasiliensis sp. n. (Gabuciniidae) from H. albicollis (Gmelin). The former differs from the type species by having, in males, the anterior projections on epimerites III towards setae $3 b$ and the adanal shield bearing setae $p s 3$ present; in both sexes, a pair of small sclerites situated posterior to setae $s e$ have flat suprategumental processes. Paragabucinia brasiliensis sp. n. differs from P. petitoti (Gaud et Mouchet, 1959) by the smaller size of the incisions in the internal margins of opisthosomal lobes of males. These mites are the first representatives of corresponding genera described from the Neotropical region. The genus Hartingiella Gaud, 1980 was previously known solely from its type species. Keys to males and females of the genus Paragabucinia Gaud et Atyeo, 1975 are presented. In addition, all previous records of feather mites associated with birds of the order Caprimulgiformes of the world are summarised.
\end{abstract}

Keywords: systematics, taxonomy, Neotropical region, Hartingiella, Paragabucinia

Nightjars (Aves: Caprimulgiformes: Caprimulgidae) are nocturnal insectivore birds, with approximately 90 species distributed worldwide (del Hoyo et al. 1999, Livesey and Zusi 2007). The feather mites associated with caprimulgiform birds are less known and relatively few species of mites have been described mainly from Africa (Gaud 1958, 1980, Gaud and Mouchet 1959, Gaud and Kolebinova 1973), with additional species being described or recorded from Australia (Atyeo 1979), Neotropics (Mironov and Fain 2003, Mironov 2011), and North America (Dabert and Ehrnsberger 1992). The only feather mite species described from a caprimulgiform in Brazil is Ascouracarus chordeili Mironov et Fain, 2003 described from Chordeiles rupestris (Spix) (Caprimulgidae). Enout et al. (2012) reported an undetermined species of Trouessartia Canestrini, 1899 (Trouessartiidae) on Hydropsalis albicollis (Gmelin).

In this paper two new species of feather mites are described from the genera Hartingiella Gaud, 1990 and Paragabucinia Gaud et Atyeo, 1975 from the famillies Xolalgidae and Gabuciniidae, respectively. An updated table of known associations of feather mites and birds of the order Caprimulgiformes of the world is presented (Table 1).

\section{MATERIALS AND METHODS}

Feather mites of Hydropsalis parvula (Gould) were collected from birds captured with mist-nets and visually examined in the field for the presence of mites. Whenever feather mites were detected, a feather was carefully cut off with a small scissors and stored in individual plastic bags; the birds were released back to the wild after the feather examination. Mites from Hydropsalis albicollis were collected in the laboratory from dead birds captured with mist-nets (authorized by IBAMA - Brazilian Institute of Environment and Renewable Natural Resources, license number 19849-1, authentication code 28111788, 27 April 2009). All mite specimens were mounted on glass slides in Hoyer's medium (Krantz and Walter 2009).

Body measurements are given in micrometers and were taken as follows: idiosoma length from the anterior end of the prodorsal shield to lobar apices; idiosoma width was measured at the widest portion at the level of humeral shields; distance between setae of the same pair was taken as the direct distance between their bases and distance between different pairs is the direct distance formed by their bases at the same side of the body; dorsal shield length was measured as the greatest length from the anterior margin to the posterior end along the midline and width is the greatest width at the widest part. The chaetotaxy of the idiosoma and legs follows Griffiths et al. (1990) and Atyeo and Gaud (1966), respectively.

Address for correspondence: F.A. Hernandes, Universidade Estadual Paulista - Departamento de Zoologia Av. 24-A, Rio Claro 13506-900, São Paulo, Brazil. Phone:5519 3526 4296; Fax: 55193526 4300; E-mail: abakashi@gmail.com 
Table 1. Feather mites associated with birds of the order Caprimulgiformes of the world (sensu Livesey and Zusi 2007).

\begin{tabular}{|c|c|c|c|c|}
\hline Mite taxa & & Bird host (Caprimulgiformes) & Locality & References \\
\hline Analgidae & $\begin{array}{l}\text { Ancyralges harpipodus } \\
\text { (Trouessart, 1886) } \dagger\end{array}$ & $\begin{array}{l}\text { Podargus papuensis* } \\
\text { (Podargidae) }\end{array}$ & New Guinea* & Bonnet 1924 \\
\hline \multirow[t]{4}{*}{ Ascouracaridae } & $\begin{array}{l}\text { Ascouracarus chordeili } \\
\text { Mironov et Fain, } 2003\end{array}$ & $\begin{array}{l}\text { Chordeiles r. rupestris* } \\
\text { (Caprimulgidae) }\end{array}$ & Brazil* (Amazonas) & Mironov and Fain 2003 \\
\hline & $\begin{array}{l}\text { Ascouracarus kosarovi } \\
\text { (Vassilev, 1959) }\end{array}$ & $\begin{array}{l}\text { Caprimulgus europaeus } * \\
\text { (Caprimulgidae) }\end{array}$ & Bulgaria* & $\begin{array}{l}\text { Vassilev 1959, } \\
\text { Gaud and Kolebinova } 1973\end{array}$ \\
\hline & $\begin{array}{l}\text { Ascouracarus michigani } \\
\text { Dabert et Ehrnsberger, } 1992\end{array}$ & $\begin{array}{l}\text { Antrostomus vociferus } * \\
\text { (Caprimulgidae) }\end{array}$ & USA* (Michigan) & Dabert and Ehrnsberger 1992 \\
\hline & Ascouracarus sp. (larvae) & $\begin{array}{l}\text { Caprimulgus climacurus* } \\
\text { (Caprimulgidae) }\end{array}$ & Cameroon* & Gaud 1980 \\
\hline \multirow[t]{5}{*}{ Gabuciniidae } & $\begin{array}{l}\text { Paragabucinia cardiura } \\
\text { Gaud, } 1980\end{array}$ & $\begin{array}{l}\text { Caprimulgus rufigena*, C. fraenatus, } \\
\text { C. europaeus, C. climacurus } \\
\text { (Caprimulgidae) }\end{array}$ & $\begin{array}{l}\text { Cameroon*, South Africa, } \\
\text { Kenya, Spain, Morocco, } \\
\text { Botswana, Moldavia }\end{array}$ & $\begin{array}{l}\text { Shumilo et al. } 1973 \text {, } \\
\text { Gaud } 1980\end{array}$ \\
\hline & $\begin{array}{l}\text { Paragabucinia ignorata } \\
\text { Gaud, } 1980\end{array}$ & $\begin{array}{l}\text { Caprimulgus tristigma*, C. batesi, } \\
\text { C. climacurus } \\
\text { (Caprimulgidae) }\end{array}$ & Rwanda*, Zaire & Gaud 1980 \\
\hline & $\begin{array}{l}\text { Paragabucinia longicaudata } \\
\text { Gaud, } 1980\end{array}$ & $\begin{array}{l}\text { Caprimulgus bates } i^{*}, \text { C. fossii } \\
\text { (Caprimulgidae) }\end{array}$ & Zaire* & Gaud 1980 \\
\hline & $\begin{array}{l}\text { Paragabucinia petitoti } \\
\text { (Gaud et Mouchet, 1959) }\end{array}$ & $\begin{array}{l}\text { Caprimulgus fossii*, } \text { C. natalensis, } \\
\text { C. climacurus } \\
\text { (Caprimulgidae) }\end{array}$ & $\begin{array}{l}\text { Cameroon* Zaire, } \\
\text { Ghana (Côte de l'Or) }\end{array}$ & $\begin{array}{l}\text { Gaud and Mouchet 1959, } \\
\text { Gaud } 1980\end{array}$ \\
\hline & Paragabucinia brasiliensis sp. $\mathrm{n}$. & $\begin{array}{l}\text { Hydropsalis albicollis* } \\
\text { (Caprimulgidae) }\end{array}$ & $\begin{array}{l}\text { Brazil } \\
\text { (Natal*, Rio Claro) }\end{array}$ & present study \\
\hline \multirow[t]{2}{*}{ Psoroptoididae } & $\begin{array}{l}\text { Pandalura oconnori } \\
\text { Mironov, } 2011\end{array}$ & $\begin{array}{l}\text { Steatornis caripensis* } \\
\text { (Steatornidae) }\end{array}$ & Trinidad* & Mironov 2011 \\
\hline & $\begin{array}{l}\text { Pandalura podargi } \\
\text { Mironov, } 2011\end{array}$ & $\begin{array}{l}\text { Podargus strigoides* } \\
\text { (Podargidae) }\end{array}$ & Australia* & Mironov 2011 \\
\hline \multirow[t]{5}{*}{ Pterolichidae } & $\begin{array}{l}\text { Aegothelichus deficiens } \\
\text { Atyeo, } 1979\end{array}$ & $\begin{array}{l}\text { Aegotheles cristatus } \\
\text { (Aegothelidae) }\end{array}$ & $\begin{array}{l}\text { Australia } \\
\text { (New South Whales)* }\end{array}$ & Atyeo 1979 \\
\hline & $\begin{array}{l}\text { Nyctibiolichus megamerus } \\
\text { Atyeo, } 1979\end{array}$ & $\begin{array}{l}\text { Nyctibius griseus panamensis*, } \\
\text { N.j. jamaicensis } \\
\text { (Nyctibiidae) }\end{array}$ & Panama*, Jamaica & Atyeo 1979 \\
\hline & $\begin{array}{l}\text { Nyctibiolichus sinuatus } \\
\text { Atyeo, } 1979\end{array}$ & $\begin{array}{l}\text { Nyctibius griseus panamensis* } \\
\text { (Nyctibiidae) }\end{array}$ & Panama* & Atyeo 1979 \\
\hline & $\begin{array}{l}\text { Gymnolichus anadorus } \\
\text { Gaud et Mouchet, } 1961\end{array}$ & $\begin{array}{l}\text { Macrodipteryx longipennis* } \\
\text { (Caprimulgidae) }\end{array}$ & Cameroon* & $\begin{array}{l}\text { Gaud and Mouchet 1961, } \\
\text { Gaud } 1980\end{array}$ \\
\hline & $\begin{array}{l}\text { Gymnolichus secundus } \\
\text { Cerný et Shumilo, } 1973\end{array}$ & $\begin{array}{l}\text { Caprimulgus europaeus* } \\
\text { (Caprimulgidae) }\end{array}$ & Moldova* & Černý and Shumilo 1973 \\
\hline \multirow[t]{2}{*}{ Trouessartiidae } & $\begin{array}{l}\text { Steatacarus bifiditibia } \\
\text { Atyeo et Peterson, } 1977\end{array}$ & $\begin{array}{l}\text { Steatornis caripensis* } \\
\text { (Steatornidae) }\end{array}$ & Ecuador*, Trinidad & Atyeo and Peterson 1977 \\
\hline & Trouessartia sp. & $\begin{array}{l}\text { Hydropsalis albicollis } \\
\text { (Caprimulgidae) }\end{array}$ & Brazil* & Enout et al. 2012 \\
\hline \multirow[t]{2}{*}{ Xolalgidae } & $\begin{array}{l}\text { Hartingiella megatricha } \\
\text { (Gaud, 1958) }\end{array}$ & $\begin{array}{l}\text { Caprimulgus europaeus*, C. fossii } \\
\text { (Caprimulgidae) }\end{array}$ & Morocco*, Cameroon & \multirow{2}{*}{$\begin{array}{l}\text { Gaud 1958, } \\
\text { Gaud and Mouchet } 1959 \\
\text { present study }\end{array}$} \\
\hline & Hartingiella neotropica sp. $\mathrm{n}$. & $\begin{array}{l}\text { Hydropsalis parvula* } \\
\text { (Caprimulgidae) }\end{array}$ & $\begin{array}{l}\text { Brazil* } \\
\text { (Santa Bárbara d'Oeste) }\end{array}$ & \\
\hline
\end{tabular}

* type hosts and countries originally reported; $\uparrow$ probably contamination

Host common and scientific names are according to Clements et al. (2013). Type specimens are deposited in the following collections: DZUnesp-RC - Collection of Acari of Department of Zoology of Universidade Estadual Paulista, Rio Claro, São Paulo, Brazil; ZISP - Zoological Institute of the Russian Academy of Sciences (Saint Petersburg, Russia); IPCAS - Institute of Parasitology, Biology Centre ASCR, České Budějovice, Czech Republic.

\section{RESULTS}

\section{Survey of species found}

Analgoidea Trouessart et Mégnin, 1884

Xolalgidae Dubinin, 1953

Ingrassiinae Gaud et Atyeo, 1981

Hartingiella Gaud, 1980
Type species: Pteralloptes megatrichus Gaud, 1958

\section{Hartingiella neotropica sp. $\mathrm{n}$.}

Figs. 1-4

Description. Male (based on holotype, with measurements for 1 paratype in parentheses; Figs. 1, 2). Idiosoma size (length $\times$ width) $289 \times 109(290 \times 112)$, length of hysterosoma 190 (177). Prodorsal shield: narrow longitudinal plate noticeably enlarged at level of scapular setae, 77 (70) long, 27 (26) wide (Fig. 1A). Vertical setae absent. Setae se 81 (79) in length, separated by 50 (50), situated on small sclerites, setae si separated by 36 (36). Posterior margins of scapular shields concave; paired separate fragments of prodorsal shield, situated posterior to setae se, bear flat bifurcate suprategumental processes. Hysteronotal shield: anterior margin convex, greatest length of shield from anterior end to base of setae $h 3161$ (160), width at widest 
Hernandes: Feather mites of nightjars

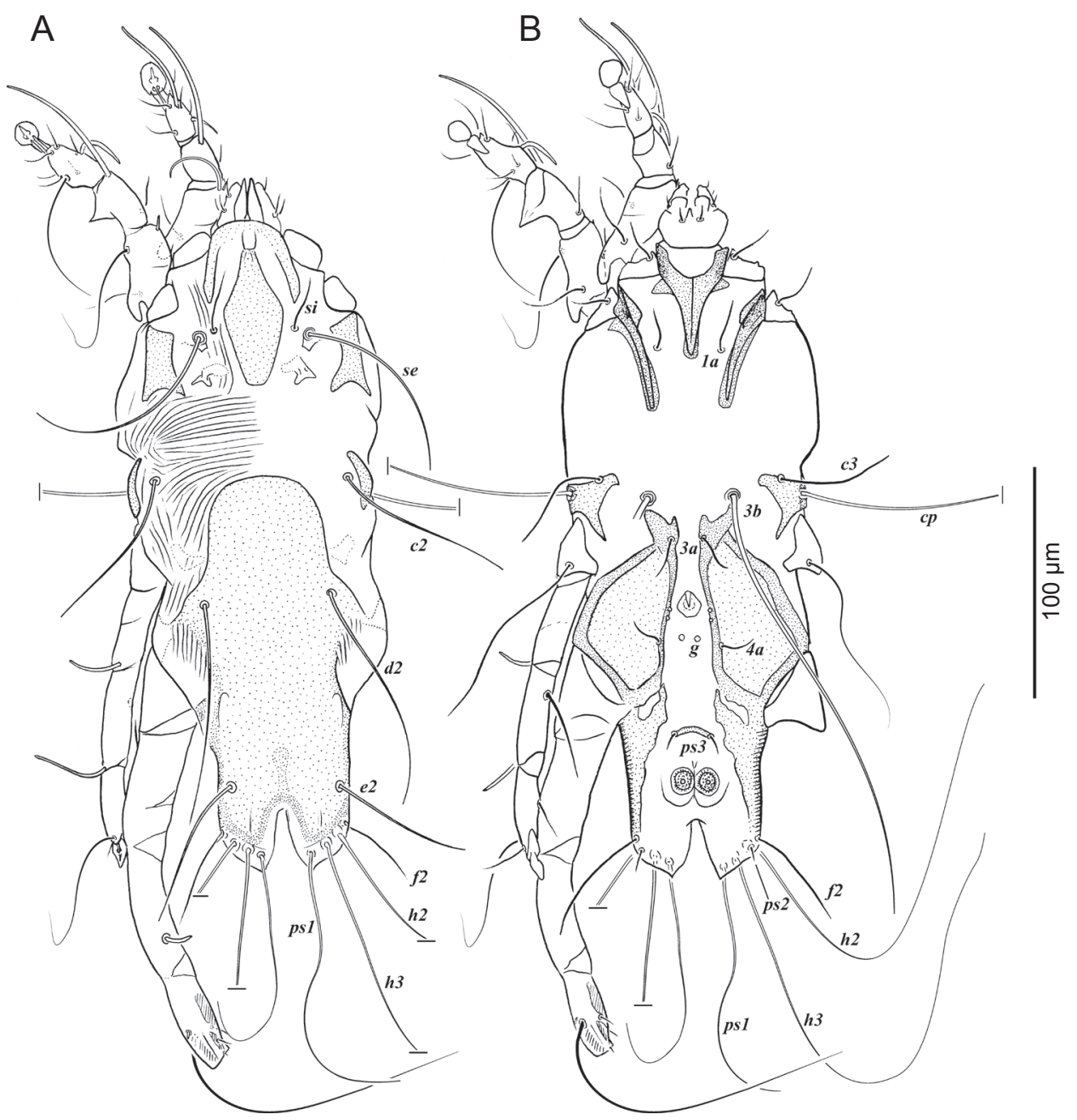

Fig. 1. Male of Hartingiella neotropica sp. n. from Hydropsalis parvula; holotype. A - dorsal view; B - ventral view.

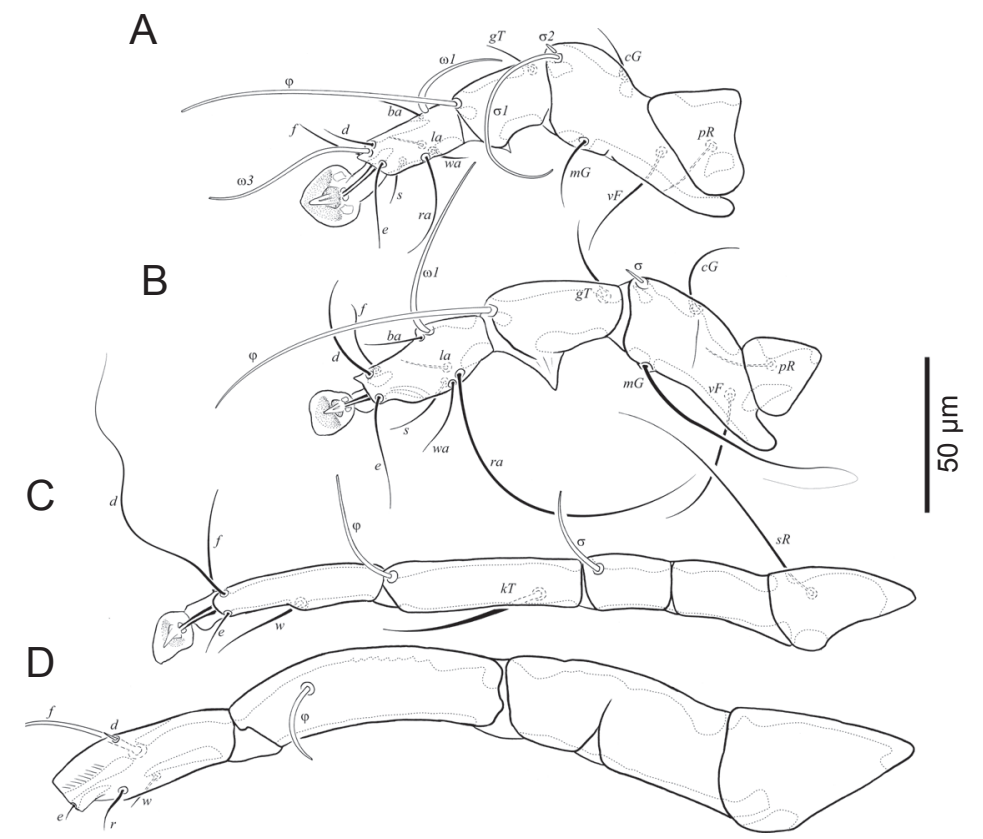

Fig. 2. Male of Hartingiella neotropica sp. n. from Hydropsalis parvula. A-D - dorsal view of legs I-IV. 


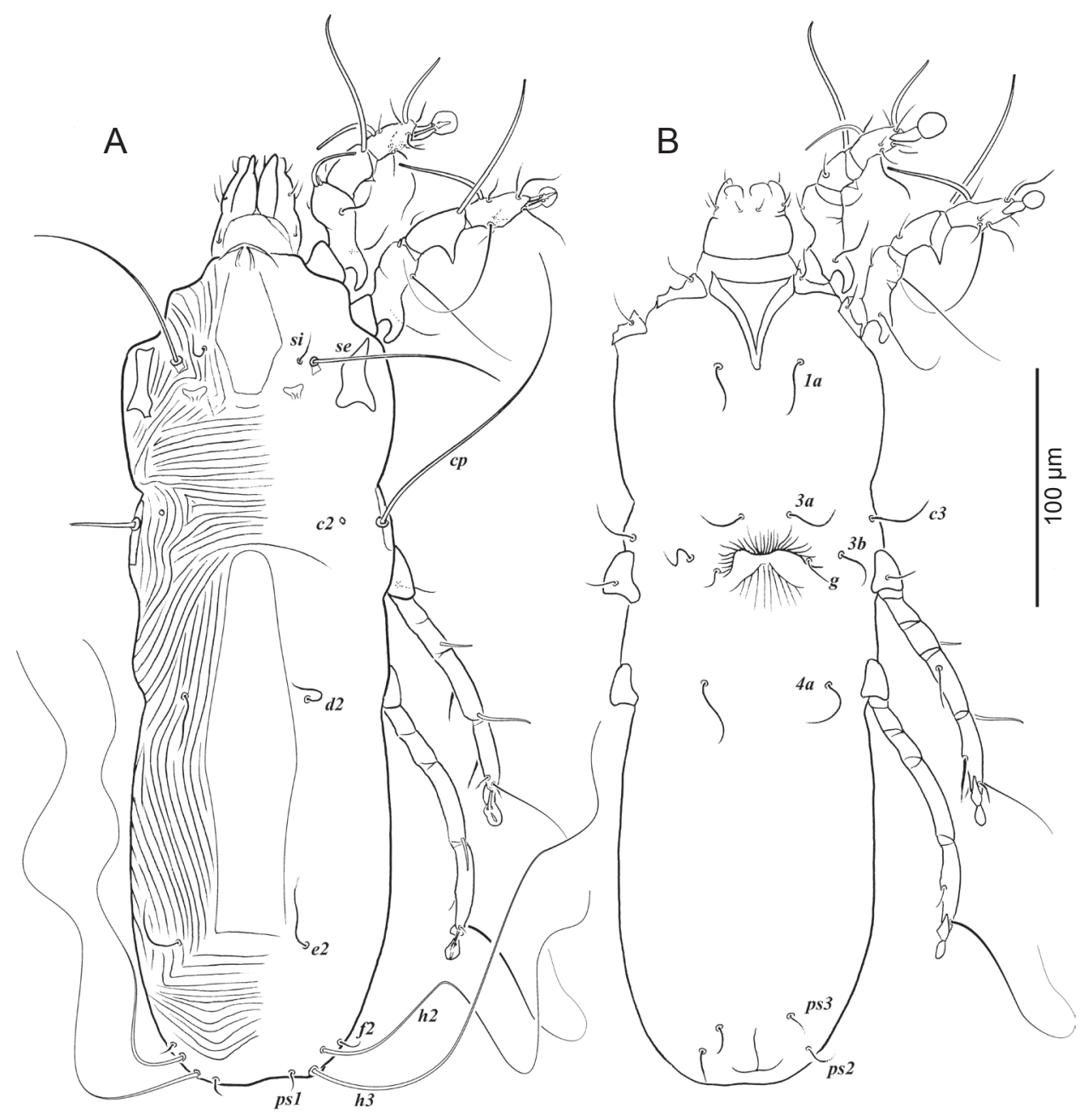

Fig. 3. Female of Hartingiella neotropica sp. n. from Hydropsalis parvula. A - dorsal view; B - ventral view.

part posterior to level of setae $d 287$ (85). Humeral shields present, dorsal part narrow. Length of terminal cleft from anterior end to tip of terminal membrane 31 (31). Supranal concavity narrow. Terminal membrane extensions on lobar apices pointed and narrow. Distance between dorsal setae: si : c2 70 (70), c2 : d2 51 (51), d2 : e2 83 (79),ps1 : ps1 23 (23), h3: h3 35 (33), h2: h2 44 (44). Setae $c 2, d 2$ and $e 2$ long, filiform, approximately as long as setae $c p$.

Epimerites I fused into $\mathrm{Y}$ with concave anterior margin, sternum approximately half total length of epimerites I. Epimerites IIa absent. Coxal fields I, II, III open. Setae $c 3$ and $c p$ inserted ventrally on humeral shield. Anterior ends of epimerites IIIa bearing bases of setae $3 b$, setae $3 a$ and $4 a$ inserted on paragenital apodemes connecting epimerites IVa and IIIa (Fig. 1B). Genital apparatus small; genital discs situated on inner margins of paragenital apodemes. Adanal shield-bow shaped, bearing setae $p s 3$ on its lateral extremities. Distance between ventral setae: $1 a$ : $3 b 63$ (75), $3 b: 3 a 22$ (21), $3 a: 4 a 45$ (41), $4 a: g 9$ (10), $g: p s 339$ (37),ps3 : ps3 16 (15). Diameter of anal suckers 10 (9), distance between centres of suckers 12 (14).
Coxal fields IV completely sclerotised. Femoragenua I, II bear rounded basal retrograde apophysis. Tibiae I with small ventral process, tibia II with well expressed acute ventral process. Tarsus I, II with small apical spine (Fig. 2A,B). Setae $m G$ and $r a$ of leg II, $s R$ and $d$ of leg III, and $f$ of leg IV much longer than other setae of these legs (Fig. 2B-D). Length of solenidia: $\sigma 1$ of genu I 46 (47), $\varphi$ of tibia I 63 (59), $\varphi$ of tibia II 78 (72), $\omega 1$ of tarsus I 23 (23), $\omega 3$ of tarsus I 35 (33), $\omega 1$ of tarsus II 40 (37). Ambulacral stalk of tarsus III with ventral round extention. Ambulacrum of legs III slender than on anterior legs and absent from legs I (Fig. 2E). Legs I, II similar in shape, legs IV thicker and longer than legs III.

Female (1 paratype; Figs. 3, 4). Idiosoma size (length $\times$ width) $368 \times 110$. Prodorsal shield: a longitudinal plate slightly enlarged in the middle part, lightly sclerotized; total length 63, greatest width 28 (Fig. 3A). Vertical setae absent. Setae se 84 in length, separated by 58 , situated on small sclerites, setae si separated by 40 . Posterior margins of scapular shields concave, small pair of sclerites present posterior to scapular setae. Hysteronotal shield: 


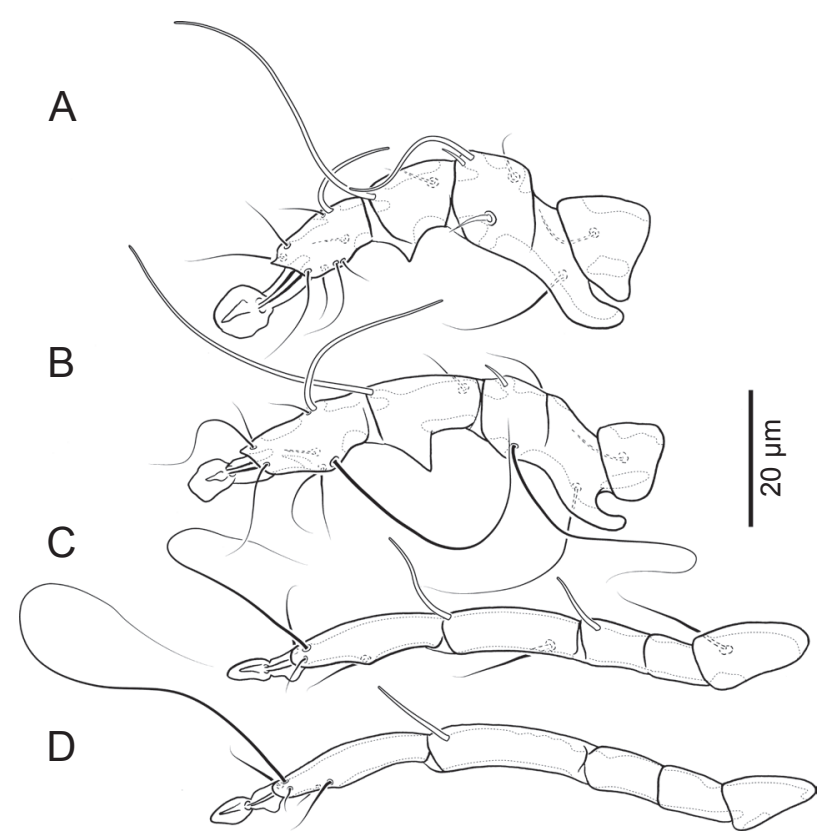

Fig. 4. Female of Hartingiella neotropica sp. n. from Hydropsalis parvula. A-D - dorsal view of legs I-IV.

anterior margin rounded; posterior margin straight; lateral margins slightly convex in medial part; greatest length of shield 161, greatest width 37 ; setae $c 2, d 2$, and $e 2$ on striated tegument, $c 2$ broken in paratype. Distances between dorsal setae: $s i: c 271, c 2: d 277, d 2: e 2$ 102,ps1 : ps 1 32, h3: h3 48, h2: h2 61 .

Epimerites I fused into a V with a small sternum. Epigynum absent, oviporus represented by transverse bowshaped folds (Fig. 3B). Distances between ventral setae: $1 a: 3 a$ 65, 3a:g 26, $g: 4 a 47,4 a: p s 3142, p s 2: p s 316$, ps2 : ps 2 42, ps 3 : ps 331 .

Legs I-III as in male, except for very short setae $s R$ III on trochanters III. Ambulacral stalks of tarsi III, IV with ventral round extension. Legs IV extending to level of setae $e 2$ (Fig. 4D).

Type host: Hydropsalis parvula (Gould) (Aves: Caprimulgiformes: Caprimulgidae).

Type locality: Santa Bárbara d'Oeste, São Paulo State, Brazil (47²5'04"S; 2249'14"W).

Type material: $\widehat{\sigma}$ holotype, $1 \hat{\delta}$ and $2 \propto$ paratypes from Hydropsalis parvula (Gould) (Caprimulgiformes: Caprimulgidae), 2 March 2013, collected by F.A.F. Jacomassa. Holotype and paratypes at DZUnesp-RC (Coll. Nos. 385-388).

Etymology: The specific epithet refers to the Neotropical region, since this is the first species of the genus described from this region; it is treated as an adjective in the nominative singular.

Differential diagnosis. Hartingiella neotropica $\mathrm{sp}$. $\mathrm{n}$. differs from the type species of the genus by having the following features: in males, the anterior projections on epimerites III towards setae $3 b$ and the adanal shield bearing setae $p s 3$ are present; in both sexes, a pair of small sclerites situated posterior to setae se have flat suprategumental processes. In males of $H$. megatricha, both the projections on epimerites III and the adanal shields are absent, and in both sexes, the suprategumental flat processes are also absent.

Remarks. The genus Hartingiella was previously monotypic, including only the type species $H$. megatricha (Gaud, 1958), described from Caprimulgus europaeus Linnaeus in Morocco, and later found on C. inornatus Heuglin, Scotornis fossii (Hartlaub), and S. climacurus (Vieillot) from Cameroon (Gaud 1980). All known hosts are from the family Caprimulgidae.

Feather mites of this genus are elongated forms, characterised by having the following features: in both sexes, femora I and II have rounded basal retrograde apophyses; in males, the posterior legs are longer than anterior ones, ambulacra are absent from legs IV, and setae $f$ of tarsus IV are extremely long (about $170 \mu \mathrm{m}$, Fig. 1).

Pterolichoidea Trouessart et Mégnin, 1884

Gabuciniidae Gaud et Atyeo, 1975

Paragabucinia Gaud et Atyeo, 1975

Type species: Gabucinia petitoti Gaud et Mouchet, 1959

\section{Paragabucinia brasiliensis sp. $\mathrm{n}$.}

Figs. 5-7

Description. Male (holotype, measurements for 8 paratypes in parentheses; Figs. 5, 6): Length of idiosoma from anterior end of prodorsal shield to tips of lobes 478 (463-501), greatest width 231 (226-240), length of hysterosoma 313 (297-328). Prodorsal shield entire, without lateral incisions, posterior margins with slight median concavity, length along midline 106 (104-118), greatest width 160 (149-166) (Fig. 6A). Setae vi 42 (33-43) in length, separated by 21 (15-23), se 236 (214-247) in length, separated by 83 (80-88), situated on prodorsal shield, setae si at same level of setae se, separated by 57 (51-61). Scapular shields narrow, with posterior margins oblique. Humeral shields present. Distance between prodorsal and hysteronotal shields 64 (55-72). Setae $c 1, c 2$ on striated tegument. Hysteronotal shield: slightly concave, width at anterior margin 203 (198-219). Setae $c 2$ and $d 2$ filiform, setae $e 2, f 2$, and $h 1$ thickened. Supranal concavity with median projection anteriorly and acute apices posteriorly, open posteriorly into terminal cleft. Setae $h 1, e 2$ and $f 2$ thick, length of setae $h 120$ (19-23), e2 19 (16-24), f2 22 (21-25). Setae h2 347 (312-368) long, h3 271 (235-293) long. Setae ps 1 spiculiform, slightly thicker than $c 2$, situated anterior to level of $h 3,15$ (15-19) in length. Distance between dorsal setae: $c 1: d 191$ (81-94), $d 1: d 238$ (40-54), d2 : e1 71 (69-77), e1 : e2 76 (56-77), $h 1: h 150$ (53-61), h3: h3 72 (77-86). 


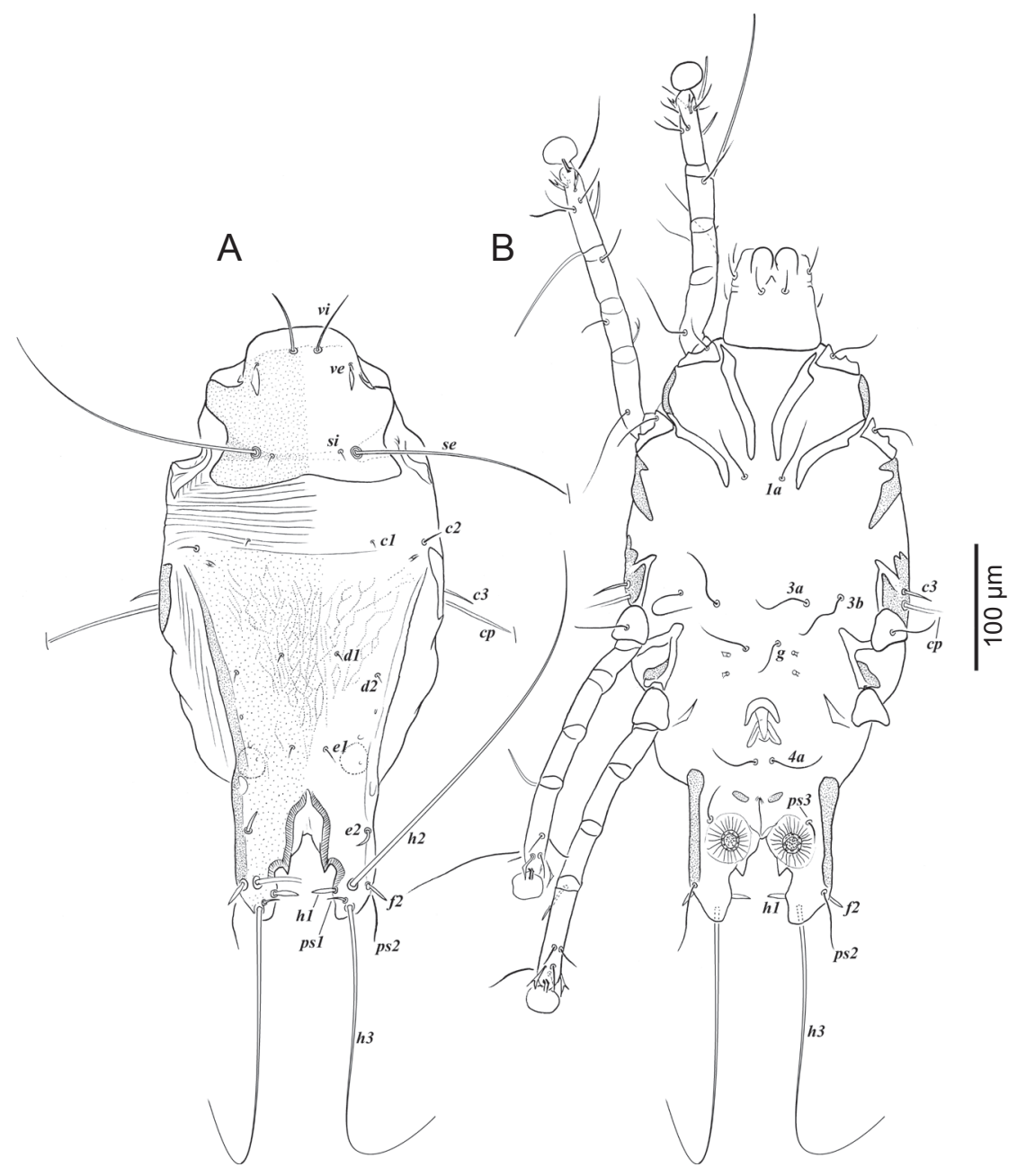

Fig. 5. Male of Paragabucinia brasiliensis sp. n. from Hydropsalis albicollis; holotype. A - dorsal view; B - ventral view.

Epimerites I free, posterior extremities parallel. Setae $c 3$ thin, spiculiform; setae $c 3$ and $c p$ inserted ventrally on humeral shield (Fig. 6B). Ventral surface without large sclerotized areas. Pregenital apodeme (epiandrium) archlike, small. Genital apparatus small, aedeagus 30 (24-32) in length, genital arch width 32 (25-31). Adanal shields present, represented by small ovate sclerites at level of anterior end of anal opening. Epimerites IVa present, indistinct. Setae ps2 40 (39-49) in length, setae ps3 25 (16-28) in length. Diameter of anal suckers 16 (17-19), distance between centers of discs 50 (51-61). Setae $3 a$ and $3 b$ situated approximately at same transverse level. Setae $g$ at level of anterior pair of genital papillae. Distance between ventral setae: $1 a: 3 a 105$ (95-109), $3 a: g$ 42 (39-49), $g: 4 a 91$ (84-102), 4a: ps3 56 (54-62), ps3 : ps3 80 (80-86).

Seta $c G$ on genu I approximately as long as genu and tibia combined, setae $c G$ on genu II distally bifid (Fig. 7A,B). Length of solenidia: $\omega 1$ of tarsus I 21 (20-24), $\omega 3$ of tarsus I 40 (42-46), $\omega 1$ of tarsus II 32 (30-36). Setae $d$ of tarsus IV situated at midlength of this segment (Fig. 7D).
Female (based on 8 paratypes; Fig. 7): Length of idiosoma 534-589, greatest width 266-294, length of hysterosoma 349-373. Prodorsal shield shaped as in the male, length along midline 115-126, greatest width 179-192 (Fig. 8A). Scapular setae si and se situated at same transverse level, on prodorsal shield. Setae vi 40-50 in length, separated by 23-28, se 256-304 in length, separated by 95-101, si separated by 66-72. Scapular shields narrow, with posterior margins oblique. Humeral shields present. Distance between prodorsal and hysteronotal shields 90-97. Hysteronotal shield: anterior margin concave, posterior part with large unsclerotized area surrounding setae $h 1$, anterior margin of this area irregularly indented; greatest width of shield 231-249. Distance between dorsal setae: $c 1: d 1$ 90-107, $d 1: d 247-59, d 2:$ el 106-120, e1 : e2 80-104, e2 : h1 32-39, h1 : h1 63-72, h2: h2 66-80, h3 : h3 43-64, ps 1 : ps 1 26-33.

Epimerites I free, posterior extremities parallel. Epigynum thick, bow-shaped, 76-87 long, 48-61 wide, tips bearing bases of setae $3 a$. Setae $3 b$ slightly posterior to level of setae $3 a$; setae $g$ slightly posterior to level of tro- 


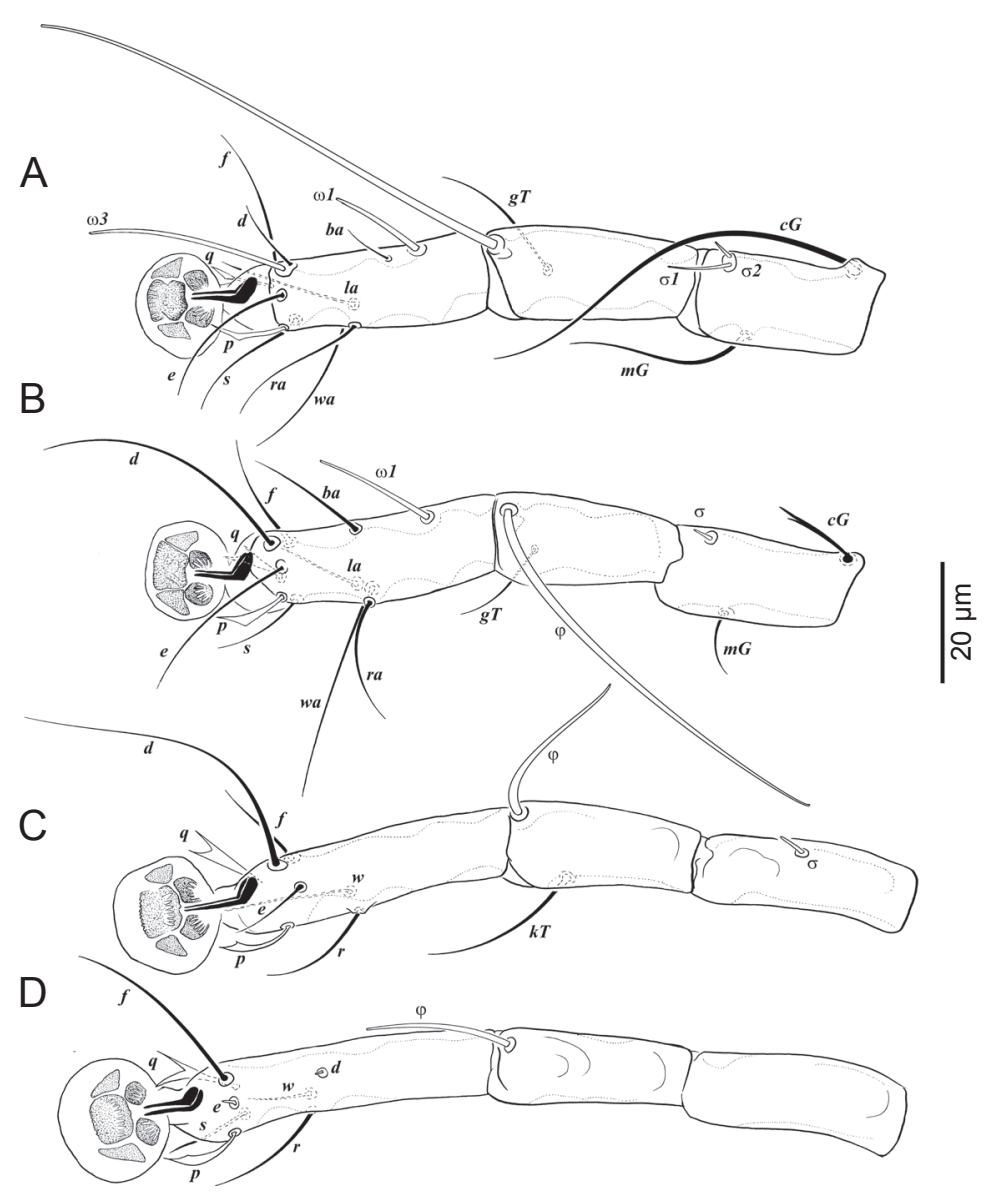

Fig. 6. Male of Paragabucinia brasiliensis sp. n. from Hydropsalis albicollis. A-D - dorsal view of tibiae-tarsi of legs I-IV.

chanters III, genital papillae posterior to setae $g$. Seta $c 3$ spiculiform, 29-34 in length. Seta h2 368-429 long, seta h3 300-387 long. Distance between ventral setae: $1 a: 3 a$ 93-108, 3a: g 58-68, g: 4a 69-86, 4a:ps3 120-148, ps2 :ps3 24-37, ps2 : ps2 53-76, ps3 : ps3 37-52.

Legs I, IV as in the male. Tarsus IV extending beyond posterior end of opisthosoma. Setae $s R$ III subequal to total length of corresponding femur. Length of solenidia: $\omega 1$ of tarsus I 21-26, $\omega 3$ of tarsus I 48-51, $\omega 1$ of tarsus II 29-40.

Type host: Hydropsalis albicollis (Gmelin) (Aves: Caprimulgiformes: Caprimulgidae)

Type lo c a lity: Mata da Escola Agrícola de Jundiaí-UFRN $\left(5^{\circ} 53^{\prime} \mathrm{S}, 35^{\circ} 23^{\prime} \mathrm{W}\right)$, Macaíba, Rio Grande do Norte, Brazil.

Type material: $\widehat{\delta}$ holotype, $15 \hat{\delta}$ and 13 o paratypes ex Hydropsalis albicollis (Caprimulgiformes: Caprimulgidae), 19 April 2012, collected by H.M. Silva.

Additional material: 23 immatures collected from the same host at UNESP $\left(22^{\circ} 24^{\prime} \mathrm{S} ; 47^{\circ} 33^{\prime} \mathrm{W}\right)$, Rio Claro, SP State, Brazil, 2 March 2013, collected by F.A.F. Jacomassa. Holotype and paratypes at DZUnesp-RC (Coll. Nos. 389-413); a male and female paratypes at ZISP and IPCAS.

E ty mology: The specific epithet refers to the country where the new species was found and it is treated as an adjective in the nominative singular.
Differential diagnosis. Paragabucinia brasiliensis $\mathrm{sp.}$ n. is most similar to P. petitoti (Gaud et Mouchet, 1959) by having an incision on the internal margins of opisthosomal lobes of males (anterior to the level of setae hl). However, it differs from the latter by the smaller size of these incisions with the acute anterior edge and by having the scapular setae se inserted on the prodorsal shield. In $P$. petitoti the lobar incisions are very large, and setae $s i$ and se are inserted on the striated tegument crossing the prodorsal shield.

Remarks. The genus Paragabucinia currently includes four species associated with nightjars of the genus Caprimulgus Linnaeus (Caprimulgidae) from Africa and Europe (Gaud and Mouchet 1959, Gaud and Atyeo 1975, Shumilo et al. 1973, Gaud 1980). A fifth species is herein described from the pauraque, Hydropsalis albicollis (Gmelin) (Caprimulgidae), from Brazil. This genus is characterised by having solenidion $\sigma$ present on genua I and II, two setae $v i$, setae $c 2$ filiform. Males have well developed opisthosomal lobes and the epigynum is long and encompasses setae $3 a$ in females. The main discriminant characters of all known genera of the family Gabuciniidae were provided by Mironov et al. (2007). 


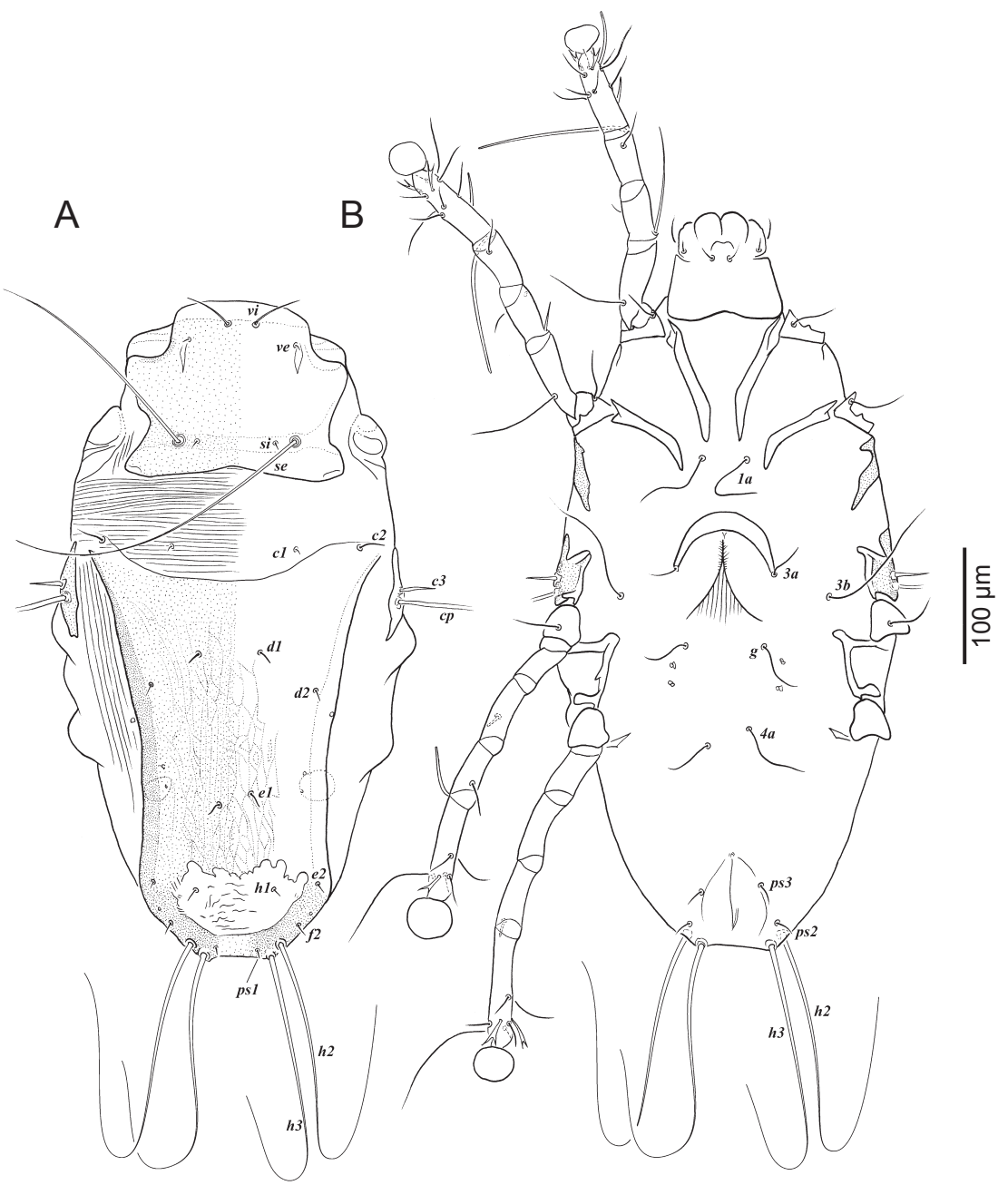

Fig. 7. Female of Paragabucinia brasiliensis sp. n. from Hydropsalis albicollis. A - dorsal view; B - ventral view.

A taxonomic note should be made concerning the names Paragabucinia and P. cardiura. Shumilo et al. (1973) reported the latter species on Caprimulgus europaeus Linnaeus in Moldavia, referring the authority of both genus and species to Gaud, and the date of their own paper - 1973. However, the genus Paragabucinia was described two years later by Gaud and Atyeo (1975), and the species $P$. cardiura was actually described by Gaud (1980) seven years later, from a different host species, Caprimulgus rufigena Smith. Shumilo et al. (1973) apparently used manuscript names provided by J. Gaud; therefore, the taxa Paragabucinia and P. cardiura as appeared in their publication are nomina nuda, since they were not accompanied by a description. The genus and species names were validated in 1975 and 1980, respectively (Gaud and Atyeo 1975, Gaud 1980).

\section{Key to males of the genus Paragabucinia Gaud et} Atyeo, 1975

1 Seta $e 2$ approximately as long as tarsus IV

- Seta $e 2$ about $1 / 5$ of the length of tarsus IV 2 3
2 Distance between setae $g-4 a$ equal to or longer than distance $g-h 1$..................... P. cardiura Gaud, 1980

- Distance between setae $g-4 a$ signifficantly less than distance $g-h 1$ P. ignorata Gaud, 1980

3 Internal margins of opisthosomal lobes with a semicircular indentation anterior to level of setae $h 1$ 4 - Semicircular indentation on opisthosomal lobes absent. P. longicaudata Gaud, 1980

4 Prodorsal shield with lateral incisions at level of setae se and $s i$, these setae inserted off prodorsal shield (in both sexes) ....... P. petitoti (Gaud et Mouchet, 1959).

- Lateral incisions on prodorsal shield absent, setae se and si inserted on prodorsal shield .... P. brasiliensis sp. n.

\section{Key to females of the genus Paragabucinia Gaud et Atyeo, 1975}

1 Area of hysteronotal shield between setae $e 1$ and $h 1$ with a pair of distinct incisions 2 .
- Paired incisions in this area absent ............................... P. brasiliensis $\mathrm{sp} . \mathrm{n}$. 
2 Paired incisions on hysteronotal shield not extending to the level of setae $e 1$ 3

- Paired incisions on hysteronotal shield extending to the level of setae $e 1$ 4

3 Anterior margins of paired incisions anterior to setae $h 1$ rounded P. cardiura Gaud, 1980

- Anterior margins of paired incisions anterior to setae $h 1$ angular P. petitoti (Gaud et Mouchet, 1959)
4 Setae $h 1$ anterior to or at the same level of setae $e 2 \ldots .$. P. longicaudata Gaud, 1980

- Setae $h 1$ posterior to level of setae $e 2$ P. ignorata Gaud, 1980

Acknowledgements. Thanks are due to Fabio A.F. Jacomassa (UNESP, Rio Claro, Brazil) and Honara M. Silva (UFRN, Natal, Brazil), for collecting the mites from Hydropsalis parvula and H. albicollis, respectively. This study was supported by FAPESP - São Paulo Research Foundation (2011/50145-0, 2011/20805-8).

\section{REFERENCES}

Atyeo W.T. 1979: New feather mite taxa (Acarina: Pterolichoidea) from the avian order Caprimulgiformes. J. Med. Entomol. 16: $528-535$.

Atyeo W.T., Gaud J. 1966: The chaetotaxy of sarcoptiform feather mites (Acarina: Analgoidea). J. Kansas Entomol. Soc. 39: $337-346$.

Atyeo W.T., Peterson P.C. 1977: Trouessartiidae, new status, with the description of a new genus (Acarina: Analgoidea). J. Med. Ent. 13: 737-741.

Bonnet A. 1924: Révision des genres Megninia, Mesalges et genres voisins de la sous-famille des Sarcoptides plumicoles (première partie). Bull. Soc. Zool. France 49: 146-188.

Clements J.F., Schulenberg T.S., Iliff M.J., Sullivan B.L., Wood C.L., Roberson D. 2013: The eBird/Clements checklist of birds of the world. World Wide Web electronic publication, www.birds.cornell.edu/clementschecklist/download/, Version 6.8.

Dabert J., Ehrnsberger R. 1992: Neue Arten bei der Federmilbenfamilie Ascouracaridae Gaud \& Atyeo, 1976. Osnabrücker Naturwiss. Mitt. 18: 109-150.

Enout A.M.J., Lobato D.N.C., Diniz F.C., Antonini Y. 2012: Chewing lice (Insecta, Phthiraptera) and feather mites (Acari, Astigmata) associated with birds of the Cerrado in Central Brazil. Parasitol. Res. 111: 1731-1742.

Gaud J. 1958: Acariens plumicoles (Analgesoidea) parasites des oiseaux du Maroc. Bull. Soc. Nat. Phys. Maroc. 38: 27-49.

Gaud J. 1980: Acariens Sarcoptiformes plumicoles parasites sur les oiseaux Psittaciformes, Strigiformes et Caprimulgiformes en Afrique. Ann. Mus. Roy. Afr. Centr. Ser. 8 Sci. Zool. 230: $1-106$.

Gaud J., Atyeo W.T. 1975: Gabuciniidae, famille nouvelle de Sarcoptiformes plumicoles. Acarologia 16: 522-561.

Gaud J., Kolebinova M. 1973: Ascouracarus vassilevi n. g., n. sp., Sarcoptiforme plumicole énigmatique parasite de l'engoulevent d'Europe. Acarologia 15: 349-355.
Gaud J., Mouchet J. 1959: Acariens plumicoles (Analgesoidea) parasites des oiseaux du Cameroun. II. Analgesidae. Ann. Parasitol. Hum. Comp. 34: 149-208.

Gaud J., Mouchet J. 1961: Deux genres nouveaux de sarcoptiformes plumicoles: un nouveau critère dans la systématique des Analgesoidea. Acarologia 3: 591-598.

Griffiths D.A., Atyeo W.T., Norton R.A., Lynch C.A. 1990: The idiosomal chaetotaxy of astigmatid mites. J. Zool. 220: $1-32$.

del Hoyo J., Elliot A., Sargatal J. (Eds.) 1999: Handbook of the Birds of the World, Vol. 5. Barn-owls to Hummingbirds. Lynx Edicions, Barcelona, 759 pp. Krantz G.W., Walter D.E. 2009: A Manual of Acarology. Third Ed. Texas Tech University Press, Lubbock, Texas, 807 pp.

Livesey B.C., Zusi R.L. 2007: Higher-order phylogeny of modern birds (Theropoda, Aves: Neornithes) based on comparative anatomy. II. Analysis and discussion. Zool. J. Linn. Soc. 149: $1-95$.

Mironov S.V. 2011: Feather mites of the genus Pandalura Hull (Astigmata: Psoroptoididae) from owls and Caprimulgiformes. Proc. Zool. Inst. RAS 315: 19-37.

Mironov S.V., Fain A. 2003: New feather mites of the family Ascouracaridae (Astigmata: Pterolichoidea) from some parrots and nightjars. Acarologia 43: 99-111.

Mironov S.V., Proctor H.C., Barreto M., Zimmerman G. 2007: New genera and species of feather mites of the family Gabuciniidae (Astigmata: Pterolichoidea) from New World raptors (Aves: Falconiformes). Can. Entomol. 139: 757-777.

VAssilev I. 1959: Acariens (Analgesoidea) en Bulgarie. Izv. Bulg. Akad. Nauk., Otdel. biol. med. nauki 3: 7-16. (In Bulgarian with French summary.)

Shumilo R.P., Černý V.V., Tikhon E.I. 1973: [Feather mites (Acariformes: Analgoidea) of wild terrestrial birds in Moldavia and Chernovitzy Oblast of the Ukraine]. Parazity Zhivotnykh i Rastenii, Akademiia nauk Moldavskoi SSR 9: 192-208. (In Russian.)

Accepted 4 December 2013 